\title{
National Determinant in Activities of the Soviet Militia (1917-1941): Regional Level
}

\author{
Vitaly A. Ivanov ${ }^{1}$, Irina A. Boyarintseva ${ }^{1}$, Victor S. Solovyov ${ }^{1} \&$ Alexey A. Ivanov ${ }^{1}$ \\ ${ }^{1}$ Mari State University, Yoshkar-Ola, Russia \\ Correspondence: Vitaly A. Ivanov, Mari State University, Lenin square 1, Yoshkar-Ola, 424000, Russia.
}

Received: February 21, 2015 Accepted: March 15, 2015 Online Published: April 29, 2015

doi:10.5539/res.v7n8p325

URL: http://dx.doi.org/10.5539/res.v7n8p325

\begin{abstract}
The article substantiates the importance of taking into account the specific of national structure in the field of law enforcement, in its regulatory framework as a necessary condition for social stability in a multinational state. The basic directions of activity of militia are shown on the basis of the systematization of a large array of a multidimensional historical and legal material in the context of the implementation of a national policy of the state. Obvious successes, mistakes and failures of militia authorities were identified in the region, the practice training of national militia staff was considered and characterized by complex and contradictory role of the so-called indigenization in line with new historiographical traditions. The author made a critical review of previous evaluation of true extent and intensity of militia's struggle with illegal actions in the sphere of international relations, detecting their involvement in the repression in 1930s, religious discrimination of Mari people. A number of practical recommendations are made in the article.
\end{abstract}

Keywords: the Soviet militia, national factor, Mari ASSR, interethnic relations, confession, discrimination, national staff, national policy, repressions, police

\section{Introduction}

The scientific and practical value of the stated theme is determined, first of all, by the fact that the Soviet militia occupied a special place in the Russian State as a system of state executive authorities. It was created as an organ of the dictatorship of the proletariat, a significant political power instrument designed for the revolution defense, the maintenance of public order and stability in the country and the region. Multinational character of the Soviet militia became its significant feature and the world's largest multiethnic, multireligious society became its scope of work. Therefore, its historical experience (both positive and negative) is an essential component of improving of internal affairs legislation.

The stated theme is of a particular interest because the national factor has been aggravated in recent decades. Ethnic separatism, ethno-political and religious and political extremism and nationalism present a serious threat to the security almost everywhere. The law enforcement agencies of many countries face great difficulties in establishing international peace and harmony as the most important condition for ensuring the security of a state (The Washington Post, 2014). This work is often lack of sensitivity and sophistication in matters of recruitment of law enforcement agencies in terms of their national membership and national traditions of the people. The reason is a bias of some of their representatives towards national forms and modes of expression. In addition, there is a lack of legislation for strengthening society needs in civil unity and reducing an interethnic tension (Hickman, 2008). In these circumstances, the historical experience of law enforcement, knowledge and records of their strengths and weaknesses may become the guarantee for a successfully resisting the challenges and risks of the new millennium.

In addition to considerations of a practical nature, relevance of topics is dictated by the need to restore historical justice. Because of the known circumstances of whole areas of activity of the Soviet militia had been ignored for years, and its role in national history had been misrepresented. At the same time until the 1980s the authorities concealed the truth in the field of national relations. Crimes committed on national causes, were often classified as disorderly conduct, they were never considered and tracked.

The historiography of the chosen problem was created in two periods: 1) Soviet period (since the late 1917 until 1980s) and 2) Russian period (since 1990s). They are characterized by different intensity of research, their 
thematic focus and conceptual differences. The fundamental trend of its development is highly dependent on political considerations and was focused on fulfillment of the ruling party's order. Notable positive developments were drawn up only in the second half of the 1980s. Training, placement and education of national staff, police involvement in resolving national conflicts, in conducting reprisals against ethnic and ethno-religious groups in the Soviet Union should be called among the key areas in studying of an impact of national factor on the Soviet militia.

However, despite considerable achievements, the impact of national factors on the activity of the Soviet militia was not distinguished separately and as an independent trend in historical and legal sciences. Almost always the stated topic was dealt with separate sections, paragraphs, as part of broader themes of the "national question" or "of the Soviet militia's activity." There are no integrated studies, specifically devoted to the subject at the present.

The above mentioned reasons and the urgency of the problem, the lack of a holistic coverage and analysis, as well as a bias approach in a number of works of the past years, have allowed the authors to choose it as a subject of the study.

\section{Materials and Methods}

The analysis of the raised issues is performed at the regional level, on an example of the Mari ASSR militia, and based on the realities of nation-building in the Russian Federation. The birth of Mari ASSR militia is indivisibly linked with the formation of the autonomy of Mari people in 1920 that was transformed into Mari ASSR in 1936. The regional Department of the militia of the Revolutionary Committee of Mari region was established by the decision of the regional Executive Committee on January 14, 1921. Since then Mari militia has joined to the fight to strengthen the rule of law, public security, create conditions for successful social and economic development in the region, inter-ethnic peace and harmony.

The chronological framework of this work is from 1917 to 1941. It's a new stage in the development of Russia as a whole and its separate regions, including the Mari region marked by radical political and socio-economic changes that have substantially affected the logic and content of law enforcement. The selected scope of the study allows tracking the place and the role of the militia authority in the totalitarian political system since its inception until its climax, marked by the domination of a single political party, the absence of a political opposition, the political party and state machine integration, mass organizations' obedience to the state, personality cult. The framework allows setting up the dynamics of events, the reciprocal conditionality of changes to the regulatory framework of forms and methods of militia's work in connection with changes in the social, economic and political situation.

The characteristic feature of the research of the national impact on the Soviet militia's activities is the need for an integrated, multidisciplinary approach with taking into account not only legal, but also historical, social, economic, political and other aspects of the problem. This work required the analysis and study of various sources and literature.

\section{Results and Discussions}

The building of a socialist society after the revolution of 1917 has significantly reduced inter-ethnic tension accumulated in the country during hundreds of years. The Bolsheviks faced the national issue as one of the main destructive factor that had not been resolved by autocracy. In these conditions, skillful management of interethnic relations, development of a meaningful national policy became the more important problem.

On November 2, 1917 the Declaration of the rights of the peoples of Russia was adopted by UPC of USSR. The Declaration proclaimed the full release of peoples from national oppression. It formulated the basic principles of the policy of Soviet power in national building: a) the equality and sovereignty of peoples of Russia; b) the right of peoples to self-determination, including the right to form an independent and separate state; in) canceled all and any national and ethnic-religious privileges and restrictions; g) gave freedom for development of national minorities and ethnic groups living on the territory of Russia. These principles were established in the first Soviet Constitution, 1918 (Section II, Chapter V, Article 22), constituting the legal basis of the national policy and in the militia.

In the first years after the revolution of 1917, the position of the militia in the Mari land was determined by an important feature that became a result of the impact of the national factor.

The militia's activity was conducted in a situation of indifferent and later a suspicious, hostile attitude to the party and Soviet authorities and low prestige of the police. First, this was due to the fact that people often transferred their hostile attitude to the tsarist police and gendarmerie to the Soviet militia. Secondly, in the minds 
of the border peoples, who in the period of tsarist empire were alienated from government and management structures, the power was always inonational, alien and often hostile (Ivanov, 2005).

Since the early days of Soviet power, great importance was given to the formation of the national republics and regions primarily among persons who knew language, life, manners and customs of their people and enjoyed their confidence. In January and February 1918, Tsarevokokshayskiy Council demanded proportional representation of Mari people in the militia. Militia officers were often expelled from their posts transferred to other areas of work in areas with high concentrations of Mari people because of ignorance of their language (29, file 98, leaf 6). At the same time, measures were taken to attract Mari women to the militia, but they, by the way, did not produce any results. The main reason was in the national Mari women mentality who were traditionally bound to their household, were not accustomed to public activities, had a low level of education and general culture, poor knowledge of Russian language. The few women who were enrolled in the militia were efficient.

The involvement of national staff in power structures, known as indigenization, was actively developed after the Xth Congress of the RCP (b), which adopted the resolution "The regular tasks of the party to resolve the national issue". The target of the adopted document was to eliminate inequality of backward nationalities, to assist in the development and strengthening of the Soviet State by the ways appropriate to their national and household characteristics, using their own language, to create a wide training network for the education of national staff.

The indigenization policy was established officially in June 1923, at the meeting of senior officers of the national republics and regions of the CC RCP (b), where the program of action for the development of economy and culture in the national republics was adopted, and, most importantly, including the program for increasing political representation of non-Russian nationalities. An extensive conversation about this also took place in May 1925 at the 3rd all-Union Congress of Soviets (About the Soviet construction, 1925). A special provision relating the national language was included in the Constitution of the RSFSR in 1925. The provision says, "The right of free of the mother tongue at the congresses, in a Court of law, administration and society is recognized for the citizens of the Russian Federation" (Section. I, Chapter I, Art. 13). National minorities had the right to school education in their mother tongue.

Within the framework of the implementation of the national policy of the State indigenization many legal acts containing specific requirements for the completion of the militia were issued. Thus, on May 6, 1927 the Administrative Department of the Mari region issued an order "Holding of the national policy in the Administration", which ordered the Mari language to be learned in all departments of the militia. It was suggested to review a network of militia districts and to sort them according to the national composition of the population, so that an officer had to know indigenous language in the district. It was supposed to use the language of the request in response to written requests to institutions and individuals. In case of sending the inquiry abroad the region the materials should be accompanied by a copy in Russian (29, file 251, leaf 74). From January 1, 1927 this practice was introduced in the regional division of administration and the cantons (26, feil 712, leaf 146). All mandatory regulations were translated, a copy of the inquest were given to Mari people in their native language.

Legal analysis of regulatory documents allows claiming the principle of the equality of nations and nationalities and the prohibition of discrimination on national grounds contained in the Constitutions of 1918, 1924 and 1936, compromised and weakened to a certain extent the advantages and benefits provided to particular nations and nationalities. The basis for such arguments are the following: preferential enrollment of indigenous persons in the workers' and peasants' militia; priority direction them for training in militia schools and other educational institutions; artificial regulation of regional militia on the basis of nationality; more liberal requirements for general education and special training of an indigenous persons (Ivanov, 2004). This example of discrimination based on nationality is not the only one. So, the order of the NCIA of the USSR N. 00310, December 21, 1938, when selecting candidates for NCIA demanded "to clip, especially, people who have Jewish blood."

The ethnic heterogeneity of peoples gave the originality to a national staff in the militia. In particular, Mari people in the region had two sub-ethnic groups -mountain Mari (their share of the total number of the Mari people was about $20 \%$ ) and meadow Mari (80\%), distinguished by the language, culture and way of life, religion and economic life. This specific feature of Mari land appeared in unexpectedly weak representation of the mountainous part of the Mari ethnic group in the militia while building up the militia staff. The share of Mari militia men in 1925 in Kozmodemyanskiy Canton was only 1.5\% (Mari village, 1925). This disparity was pronounced in a timely manner. The 4th regional party conference in February 1927 proposed to take "the interests of the mountain Mari people" into consideration. At the same time it was ordered to continue the clarification of national policy, to enhance and nurture national party activists, to address resolutely the ideas of 
great-power chauvinism and local national isolation (20, file 334, leaf 13).

Political and economic strengthening of the Soviet state after the formation of the USSR and the adoption of the first Federal Constitution contributed to the growth of national personnel in governance, enhancing of their social and political activity. In 1925 Mari people constituted 23\% in regional militia, in 1926 the proportion of Mari people was 40\%, and 47\% in 1927 (28, file 262, file 91). For comparison: on January 1, 1927 the specific gravity of the nationality, that gave the name to the area amounted to $39 \%$ of Votskaya AR, Kalmyk-59\%, Komi-94\% in the militia.

In the 1920s the great work of involving of national staff in the militia and the transition to serve the population in their native language gave different results. On the one hand, this work was an important condition for increasing the credibility of the Soviet militia in the population opinion (23, file 146, leaf 4). Many Mari workers integrated the provincial militia, were actively involved in the armed struggle against external and internal counter-revolution, public order protection, fight against crime.

On the other hand, the process of indigenization was dramatically compressed in time and was conducted using pretty crude methods, without the necessary care for the preservation of skilled staff and the gradualness of changes. So the process spawned unhealthy relationships among militiamen (28, file 262, leaf 19), "the passivity at work because of an expected dismissal" (30, file 110, leaf 42). The indigenization policy and implementation of Mari language were named the main source of discontent among Russian population in the information of the regional party Committee of the CC RCP (b) in summer 1927 (20, file 359, leaf 83). This created a breeding ground for nationalism and prevented the normal organization of the work of the militia. However, there were no examples of an open resistance to the indigenization, though, a hidden grudge was noticed on the side of particular managers, sometimes attributed to the discrimination of Mari using specious arguments (26, file 802, leaf 5).

The indigenization in 1920s is an attempt to address the negative effects of the deformed tsarism policy against small populations, the policy, which was aimed at their alienation from government, education and culture. It was designed to compensate "the mistrust, the suspicion, and the bitterness that were marked ... the government of the "power of the nation in the historical past." After October 1917 peoples' national identity was waked by major events demanded to meet the increased ambitions and, especially demanded the power. Immediately and instantly. However, the indigenization turned up to be greatly flawed due to distortion in the process of its implementation (it limited recruitment practices by business signs, introduced certain points of restriction of the rights and the elements of coercion towards persons of so-called non-indigenous nationality, gave rise to new tensions in the sphere of inter-ethnic relations) became quasi necessary, justified in the name of the approval of the national peace and harmony. And not least, to preserve the existing authorities.

The staff forming feature in the 1930s along with the requirements for strengthening the soviet-party staff by the national staff, including the militia authorities, the further spread of the Mari language, was the task to "clean" management departments from the nationalist staff". Repressions against national staff were carried out in party, government, public organizations, and against officials of the national culture. The initial successes of forming the multinational state were significantly broken by the violations of legality in the period of Stalin's personality cult. This caused severe damage to sensible trends in indigenization of the militia.

It seems that the controversy was created by the nature of the indigenization that provided significant benefits to representatives of the title nation upon appointment to office. In this regard the indigenization in the region was manifestly unfair to Russian population, because the accelerated integration of Mari people in the militia was accompanied by a decrease in the proportion of Russian-speakers among militia officers and reduced their number often to the detriment of the plans. Of course, the indigenization policy flawed itself as a way of harmonizing inter-ethnic relations and should not be allowed to exist in a civilized society. But it could be useful in this specific historical period if it had been conducted in the form of systematic work on training indigenous staff, improving their cultural, educational, and professional levels, and the conformity of the applicants' to the required qualifications.

Workers from Centre were often directed to regions in order to strengthen the vertical of power. At first it was a forced necessity and deserved attention, and it was useful and effective. Over time, however, such "nomination", and "movement" of staff revealed significant deficiencies and were a testament to serious shortcomings in the training of local personnel. They indicated a lack of proper system operation. A lot of militia appointments were held by people who were not familiar with local conditions, the nature of militia work. They often underestimated the challenges of nation-building, made haste, and administration, did not take into account the local conditions and customs. Besides they sometimes showed neglect and arrogance to local workers, allowed 
indiscipline, violated the law. All this caused just resentment and subjected to harsh criticism at party meetings, bureau, plenary sessions, and Executive Committees meetings. Some of these appointees were poorly educated and professionally unprepared, and in local leaders' opinion, "turned out to be frauds (18, file 2824, leaf 326)." Therefore, we believe that the positive assessment of "nomination" carried out by Centre, unambiguously established in the patriotic historiography is required to be substantially adjusted.

The attention to the problems of militia national personnel was reduced at the end of 1930s. They were obscured by the activities in preparation for the imminent war. Authorities increasingly were guided by business considerations while conducting appointments. The role of qualification increased. However, there were few trained Mari workers, who did not need a "privileged appointment" and were capable to withstand a growing competition for vacant positions in the Mari militia. It was impossible for backward people to overcome the consequences of a centuries-old discrimination under the tsarist regime for a couple of decades of soviet power. The result manifested immediately: the specific share of Mari nationality in the total number of regional militia declined and amounted to $34.6 \%$ (23, file 10, leaf 138) in September 1939 against only 54.6\% in 1933 (20, file 734, leaf 179).

To assess the activities for indigenization in whole, it should be emphasized that in spite of the shortcomings of nation-building period, radical changes in the economy, culture and national relations in the Mari ASSR in the pre-war period, the indigenization contributed to strengthening the militia national staff. Many representatives of indigenous nationalities were nominated the militia officers in 1930s. Mari representatives F. V. Vershinin and N. N. Makeev were managed the regional militia, along with Russian representatives M. A. Pavlov, M. F. Nikiforov, and Z. A. Fatyanov. It is impossible not to notice the uneven character of staff forming, low level of indigenous persons' involvement in $\mathrm{CD}$, to the commanding staff of the district and regional militia departments and the absence of positive developments in these activities over the years (Ivanov, 2013).High requirements for educational level and special training of this category of workers became the reasons of this phenomenon. Meanwhile, there was few trained staff in the region.

Another key activity of the Soviet militia, due to the national factor was the fight against offenses committed on national grounds. It must be admitted that the overthrow of the autocracy in 1917 freed the territory of the national border lands' nationalist energy of enormous power. It reanimated half-forgotten historical accounts and mutual claims to demand justice. In MAO with renewed vigor's given to know some contradictions anddifferencesbetweenpredominantlyRussian-speakingpopulationandMari. About independent interest claimed as mountain Mari and Tatars. These sentiments were leaking on the pages of newspapers, manifested at party plenums, offices, various meetings and conferences (20, feil 337, leaf 24)

In the context of the revival of national consciousnesscontradictionsthemselvesoftentakeacute,heard"before the bloody clashes", during which there were dead and wounded(The Congress o the Mari people, 2008).For example, in July 1918,the citizens of the village Small Bitoman Sotnurskoyparish Tsarevokokshaisk County numbering 60persons and more Bitoman (100) attacked the village Biknarod. The attackers were armed with rifles, pitchforks and clubs. They immediately began to rob and beat up anyone who caught their eye. As a result, the village had stolen things and products worth over 18 thousand rubles. Fearing threats from robbers, residents were asked to increase the number of militiamen in the village (27, feil 10, leaf 229-230). Such conflicts between the inhabitants of separate settlements, which based on national motives, were not uncommon (Ivanov, 2006).

Militia bodies in a timely manner preventing conflicts, contributed to the approval not only of economic and political foundations of the Soviet state, but also inter-ethnic harmony in the region. The accumulated debris of mutual distrust and national enmity gradually digged. The basis for this were as historically good relations of peoples to each other, and enshrined in the Constitution of the RSFSR deliberate policy, based on the ideology of friendship and mutual assistance of the peoples (Constitution (fundamental law) of the RSFSR, 1918).

Crime in the ethnic regions of the country, of course, had its own peculiarities (Ivanov, 2005).Initially, they were reflected in 1924in the chapter "domestic crimes" of the Criminal Code of1924. These novel shave acted only in9autonomous republics and regions of the RSFSR, where preserved remains of tribal and patriarchal-feudal relations were still common practices that, from the point of view of justice backward certain categories of workers, is not a crime. Practical implementation of the Criminal Law institute showed its importance. As a result, an additional study was conducted criminal law, together with representatives of all national regions (Nedobezhkin, 2002).A similar discussion took place in the Mari Autonomous Region. The reason for it served as a special request NKJU on 26 February, 1926. In the discussion attended by representatives of the regional executive committee, administrative bodies, regional court, prosecutors and scientists. The results of which were enshrined in the Criminal Code of the RSFSR1926in the form of a special chapter" Crimes constituting remnants 
of the tribal system", the effect of which has now been extended to the entire country. When making the final version of the Penal Code, many suggestions made in MAO in the document were not logged in (Bezborodov, 1926).

Given the nature of domestic crimes, it can be noted that in the new document the most important for Mao became the criminal law to combat the practice of so-called law of the fist. The fact that the offense was the origins of which date back to ancient national customs and traditions of the Mari people, unfairly attributed comic custom pillow beating recently a married woman in holiday "Shoryk-Yol" (Yuletide), attack members of the wedding train, beating their not angry, disabling carts, harnesses, clothing; not taken a beating in the army due to health officials. Traditional exile were also whips, rods, sticks "evil forces" of the people, animals, buildings during the holiday "Surem"; ransom demanded by young people from the groom, the bride who came from another village, sometimes accompanied by threats, bullying and others. Many of these practices were symbolic, comic character, but sometimes they have criminal consequences.

In legal practice the Mari militia prosecutes for these reasons were not uncommon: in 1929the share of those was $0.4 \%$ (30, feil 75, leaf 89-91), in 1940-1.6\% (31, feil 73, leaf 170).At the same time, unfortunately, the legal acts used to combat not only with criminal consequences of patriarchal attitudes, but also to eradicate themselves traditions and customs that had often-profound social and moral sense. Such did to improve the crime situation in the country and the region a little bit, but rather exacerbated it. Therefore, the main tool to prevent this from happening, prevent the growth of crime in national regions should have been a decision not only socio-economic but also cultural and moral issues.

New aggravation of international relations was associated with the industrialization of the country, part of which is the formation of the national sections of the working class. With the growth of industry in the city many thousands of people streamed out of the national borderlands, a little familiar with the traditions of urban life, insufficient knowledge of the Russian language. In industrial enterprises and capital construction, being in a foreign environment, they are often subjected to on the part of Russian workers to violence, abuse, and discrimination and tacit, etc. With regard to the Mari Autonomous Region is very significant is the recognition of the Central Executive Committee instructor F. A. Vildanov on the audit working conditions at industrial enterprises of the region in the late 1920s. He reported to Moscow that in the "not taken to obsolete national antagonism among Russian and Mari workers". It is not uncommon abuse of female workers, Marijke that pass with impunity in front of the local organizations (Kulikov, 1993). This attitude, in particular, took place at the “Mari” (20, feil 497, leaf 57), "Red steklovar" (20, feil 337, leaf 70) and other enterprises.

Assessing this trend, the journal "Soviet justice" in 1932 noted that chauvinism - the phenomenon is quite multifaceted. Chauvinist not just name-calling mockingly derogatory word, not only openly, publicly poison him, beats, mocks, but also organizes againstnacithinly masked campaign of persecution Black Hundred, intentionally "does not see" it needs, requests, diseases, abusing his official position pinching the rights and interests of members of a small nation (The Soviet justice, 1932).

Strongly condemns the Russian chauvinism and decisions of party and government bodies. They contain a statement of the need for maximum sensitivity and compliance to national minorities. There were requirements as soon as possible to get rid of national antagonism to intensify law enforcement efforts to eradicate it (20, feil 492, leaf 225). Is condemned that "these offenses are not getting a proper rebuff", "not prosecuted person admitting neglect and hostility to national minorities", "enough is a struggle against local nationalism" (20, feil 629 , leaf5). There were demands to enhance the educational work among young people, measures for the timely resolution of its social problems (20, feil 630, leaf 299-300)

In practice, another approach was prevailed, gave results such as denial of traditions and culture of chauvinism and nationalism.

It is often has begun the practice when the militiamen, as, indeed, and others, not only condemned, but also patronized media nationalism "their" nation. In the fall of 1931, described the behavior of the chief of the ROM as the "Great Russian chauvinist conciliatory attitude" Zvenigovskykantkom of the Bureau of the CPSU (b) was proposed to discuss it further action (22, feil 107, leaf 13). The reason for this decision was the chief of militia inaction Gubarev, who disregard the application of the two-Marie workers exposed to all kinds of abuse and attempted rape.

Kantkom of the party took a principled and consistent position, in a short time repeatedly returned to the discussion of such questions: "On the abuse of women workers-Marie on Lopatinsky construction" (12 November 1931) and "On beating workers at Mari Lopatinsky plant" (April 14, 1932 year).Somewhat later kantkom of the Party considered the decision a militia cell CPSU (b)"On the facts of great-power chauvinism" 
(May 8, 1932)(22, feil 122, leaf 180), and the question "about beating students Mari Pedagogical School", a group of young people from Zvenigovo. RUM chief S. K. Kirillov was asked to bring to justice the perpetrators of the crime, and check" all doubtful citizens" in the village (22, feil 162, leaf65).

October 13, 1933at a joint meeting of the Zvenigovsky Office District Party Committee and the Presidium of the District Control Commission, where the results of the survey were heard judicial district, the brigade of the Regional Control Commission RCT stated:"Judicial and investigating authorities are not clearly comply with the directive RKVKP (b)the Anti-great-chauvinism and narrow nationalism"(22, feil 162, leaf61).

Facts of insults and physical violence based on national grounds, received publicity in other areas as well. It was discussed on February 6, 1932at the offices of Marie-Turek District Party Committee (24, feil 132, leaf 52). Here, on March 1, 1935wasconsideredthe explanation by the militia chief A. V. Domracheva" On beating student-Tatar Kurmashevoy Russian students in the Russian-Noledurskoy school” (24, feil 157, leaf 55).

On May 9, 1937the regional committee of the CPSU (b) supported the decision of Yoshkar-Ola City Party Committee to expel a member of the CPSU (b) the chief of the Pomary railway station A. P. Novikov for" a manifestation of great-power chauvinism and violation of revolutionary legality". The reason for that decision was his rudeness and bullying in dealing with a group of collective farmers-Marie, which led to an armed clash between workers and villagers at the station, which gave to serious consequences for both sides. He was named guilty and sentenced to 3 years of the imprisonment (21, feil 210, leaf 117).

Due to the policy of the Party and the state, aimed at establishing inter-ethnic harmony, unity of peoples, as well as the efforts of law enforcement agencies for the prevention and timely suppression of ethnic discrimination, and even conflicts on a national basis was laid the foundation for a new social community - the Soviet people, which is particularly clearly showed international solidarity during the Great Patriotic War.

Of course, the strengthening of the administrative-command and Party influence on the militia increasingly turns it into a compliant mechanism of the repressive machinery of the totalitarian regime (Louise L Shelley, 1990). Militia as an integral part of the state apparatus was involved in the repression period of Stalinism. Firstly, it was directed against the national intelligentsia, who grew up during the years of Soviet power. Repression in 1937-1938, included in history as the "Great Terror" were aimed at the destruction of any opposition to Stalin's leadership, the elimination of the so-called" socially alien elements": intellectuals, officers of the royal armies and white, commercial and industrial bourgeoisie, the rich peasants, clergy and others. There were many members of those social groups previously fought against the Soviets (Ivanov \& Soloviev, 2005). However, in the course of their destruction, of course, wore unfounded, criminal nature.

In the Mari ASSR, unlike many other regions, territories and republics, the repression carried out based on accusations of nationalism orchauvinism on issues related to national development, ethnic identity and nation building. Local people accused of undermining the Soviet state, they also accused organized a counter-revolutionary activities to create the Finno-Ugric federation under the protection of bourgeois Finland and exclusion throughout the territory of Finno-Ugric peoples of the Soviet Union. (Kulikov, 1993) Therefore, the number of the repressed in the Mari ASSR was especially great. Judging by the control figures, deflated by the Centre in 1937, for every thousand inhabitants in the countryplannedreprisals3.1personin the Bashkir-0.63, Mordovia-1.5, Tatar-0.68, Udmurt-0.57, Chuvash ASSR-1.67man.In this repression in the first category, the death penalty, in the Mari ASSR was planned to cover3 times more people than in Bashkortostan, Tatarstan and Udmurtia.

In 1930s the authorities of NKVDMASSR and the USSR was fabricated a number of major cases, among them - on the counter-revolutionary bourgeois-nationalist, Trotskyite-Bukharin and insurgent and terrorist, subversive and sabotage and espionage organizations (November1937). To the case were involved in such prominent political and social worker, of science, of literature and culture, as I. P. Petrov, A. F. Eshkinin, V. A. Mukhin, G. G. Karmazin, S. G. Chavayn, M. I. Vetkin, A. D. Kedrov and others. Especially” bloody" days were9-11May 1938, when the visiting session of the Military Collegium of the USSR Supreme Court sentenced to death21 representatives of the political elite of the Mari ASSR (Sultanbekov, 2002).

In 1938, there were several groups were made as "enemies of the people" solely from the mountain Mari. In April 1939, the regional committee noted with satisfaction that all the39 people who signed the statement Mountain Mari autonomy repressed (Sanukov, 2003).In general, the victims of the Great Terroron national grounds amounted to $10 \%$ of all those arrested in 1937-1938 (Native History, 2000).

The authors have no general statistics of the convicted by a militia line during the repression, but preserved in the archives of some of the figures that give an idea of the mass of the events described. In 1937, the RCM has 
been convicted239people (including shot-more than 40). In 1938, according to incomplete data, the punishment suffered 90 people including four people were sentenced to death.

The militia were involved in the persecution of religion, honor and dignity of the believing population. In that, MAO activity was particularly notable: the militia involved in the elimination of the "sacred" groves, banning collective prayers of believers Mari. The legal basis for this was the Decree of the Central Executive Committee and SNK of the RSFSR" On Religious Associations" dated April 8,1929 (The legislation on religious cults, 1971),the ban worship in the open air and thus putting paganism, at a disadvantage compared with other faiths. It deprived the pagans to worship their gods."Take decisive action against the pagan clergy as agents of the kulaks, to deprive them of voting rights, excluded from collective farms, to eliminate the "sacred groves" -a resolution instructing the Bureau OKCPSU (b)" On the activity of MAO by paganism" (September 1934) (Jaltaev, 2001).

On the way to inequalities between believers and at heists went the 1936's Soviet Constitution, approved the rights of citizens" religious worship or conduct atheistic propaganda". Thus, one can actively oppose religion, while others were allowed only" to worship" (art. 123).As a result -all sorts of efforts of law enforcement officers to protect the requirements of the Basic Law, aimed at preventing worship Mari pagan, being formally legitimate, consistently violate human rights in the field of religion.

The last decade marked the beginning of a fundamental turn $n$ the evaluation of the national factor in the life of Soviet society and the state of that period; substantially change the nature of the problem. Here are just some of its fragments.

Firstly, in the national historiography number of issues of national relations in the USSR were portrayed very simplistic. Monolithic unity, the triumph of internationalism, the rise and convergence of nations, a high rate of development of the former national borderlands, showing its real value in certain social conditions that made up story lines conceptual approaches of those years were to a certain extent exaggerated or even invented.

Secondly, many troubles in the sphere of international relations were the result not only of the colonial policy of tsarism, but were largely generated by inept social policy of the new authorities, the actions of the militia.

Third, the activities of the militia bodies for the prevention and suppression of crimes based on national motives, being very significant differed sufficient intensity and magnitude.

Fourth, it is especially important national factor manifested in organizational and structure of militia.

Enhance training and extension workers in the militia once backward economically, culturally regions became republics and regions included in the overall complex tasks of socialist construction, the creation of a federal state, its organs of power and control. Taken steps in this direction signified an important step towards harmonization of international relations, strengthening of friendship of the peoples of the USSR, the elimination of de facto in equality between them. At the same time in the late $20 \mathrm{~s}-30 \mathrm{~s}$ of the last century, there was a tendency to ignore national issues, courses on unification, the assimilation of nations and peoples. Many values are not only national, but also to develop within them regional and local cultures were enlisted in the category of "remnants" manifestations of "barbarism", "religious dope" and sentenced to oblivion. Simultaneously with the implementation of tasks flourishing and convergence of nations, a policy of leveling significant national characteristics, distorts the history of nations. A heavy blow to the people of Russia, in particular, the Mari ASSR was done in the 1930sby Stalin's repression that led to considerable destruction of national cultures and spiritual values.

Based on this analysis it is possible to formulate a number of practical recommendations.

Legislation of the Russian Federation in the field of international relations does not fully meet the needs of society to strengthen civil unity, inter-ethnic tensions, does not contain provisions that promote inter-ethnic dialogue, ensuring civil peace and interethnic harmony.

The law enforcement system of the management in the sphere of state national policy is not resolved issues of inter departmental and cross-layer coordination, early warning displays ethno phobia, radicalism and extremism in the regions and municipalities. Maintaining inter-ethnic harmony, a rapid resolution of potential conflict situations, the promotion of dialogue, promoting mutually respectful relations between members of different ethnic communities were not included organic component in the internal affairs bodies and their employees.

In the course of countering new challenges legal enforcement bodies do not always show the proper correctness and efficiency. Often, their efforts area cause for aggravation of international conflicts, lead to a decrease in the authority of law enforcement and law enforcement officers themselves. Factors impedes effective state national policy, are corruption, vices legal enforcement system, distrust of citizens to the authorities and management, 
bias of some of their representatives to the form sand methods of expression of individual nationalities, the failure to provide justice, to protect the legal interests of the people.

There is an urgent need for an objective and comprehensive research of historical and legal problems of Soviet regional militia in the context of the impact on it of the national factor. In order to further scientific knowledge of the history of the Soviet militia should continue to develop relatively unexplored aspects of its activities aimed at ensuring international peace and accord (Ivanov, 2014). Perspective can be a study on the role of the militia in the organization and conduct of repression, deportation of peoples; particular, the structure and dynamics of crime regions; nation-building and organizational form, the structure of local law enforcement. In short, you need to solve the problem of creating major scientific papers on the problems of national development dimension in the activities of the militia. The preparation of such fundamental work, in our opinion, should be a team. Developer and organizer of the execution of the research project could be the Academy of the Interior Ministry, which has experience in similar studies in the70s of the last century. To work could be attracted leading experts of the problem of universities of the Ministry of Internal Affairs and other organizations.

\section{Conclusions}

Analysis of the legal documents allows naming a few of the identities of the Soviet militia from national regions. First, it is important to emphasize that the recruitment of its personnel was carried out based on reasonable protectionism for national staff, which was due to retardation of national regions, the need for harmonization of international relations, the authorities' desire to win the support of revolutionary transformations undertaken by the Bolshevik Party. These features, however, did not include differences in the legal status of employees on a national basis.

Another feature of militia activity at the regions was its participation in the repression of criminal acts, which attended by the motives of national hatred and hostile relations on a national basis. She also actively fought against offenses, whose origins date back to ancient national traditions and customs of the peoples, the legal basis which was counter addition to the Criminal Code of the Russian Federation- "Offences constituting remnants of the tribal system".

Finally, it should be noted that due to the specific historical, national and climatic conditions Mari region of the legal basis for the organization and activities of the regional militia had features that were not inherent in all regions. Thus, in its law enforcement took place considerable opposition to religious offenses relating to the persecution of the Mari population profess paganism and devoid of legal guarantees of equality with other faiths. Another distinctive feature of the repressive law enforcement bodies of the republic were particularly important its scope, due to the fact that its citizens along with the responsibility for undermining the socialist system, the Soviet state and the counter-revolutionary activities, was charged with accusations of nationalism or chauvinism.

In conclusion, it should be emphasized that at the beginning of the Great Patriotic war was outlined to create a new organizational-legal model of the militia, in terms of both content and form, the established adequate totalitarian regime. Despite the obvious progress of militia law made since October 1917, it does not provide the full and proper respect for the rights of man and citizen. However, in spite of the imperfections of the legal framework of the Soviet militia since its inception has played a key role in the implementation of state policy, opposed by crime, carrying law enforcement to ensure the safety of citizens.

\section{References}

Bezborodov, S. (1926). Domestic crimes in the Mari autonomous region. Weekly of Soviet Justice, 21, 666-667.

Constitution (fundamental law) of the RSFSR. (1918). SUR RCP of the USSR (No. 51, article. 582).

Ferguson police officer won't be charged in fatal shooting. (2014, November 25). Ferguson protests: Calmer scenes after night of violence-As it happened. The Guardian.

Ivanov, V. A. (2004). About some questions of the indigenization of the Mari militia in the 1920th. The formation of the historical interaction and cultural ties of the Finno-Ugric peoples, 291-296.

Ivanov, V. A. (2005a). The police in the Mari region, 1917-1941: Problems of organization and operation (p. 57). Moscow.

Ivanov, V. A. (2005b). The structure, dynamics and specifics of the crime in the national region in the 1920th. Regional aspects of economics, management and law in modern society, 134-143.

Ivanov, A. A. (2006). Documentary evidence of inter ethnic relations of the Mari and Russian peasants in MAO (1920-1921). The Mari archaeological bulletin, 16, 150-159. 
Ivanov, V. A. (2013). Ministry of Internal Affairs of the Republic Mari El in the realization of the state policy: 1985-2010th. Yoshkar-Ola.

Ivanov, V. A. (2014). The problems of the historiography of the law enforcement and judicial authorities in the soviet and post-soviet periods. The Mari archaeological bulletin, 24, 51-62.

Ivanov, V. A., \& Soloviev, E. V. (2005). The specificity of the rule of law in the activities of the police of the Mari ASSR after the "great terror" (pp. 36-50). Saransk.

Jaltaev, I. F. (2001). The struggle against religion in the Mari Autonomous region in the years of collectivization. Christianization of the peoples of the Middle Volga and its historical significance. Proceedings of the regional scientific, 132.

Kulikov, K. I. (2004). Nation building in Eastern-Finnish peoples in 1917-1937th (p. 204). Izhevsk.

Louise, L. S. (1990). Policing Soviet Society: The Evolution of State Control. Law \& Social Inquiry, 15(3), 479-520. http://dx.doi.org/10.1111/j.1747-4469.1990.tb00379.x

Matthew, J. H., Alex, R. P., \& Joel, H. G. (2008). Toward a national estimate of police use of nonlethal force. Criminology \& Public Policy, 7(4), 563-604. http://dx.doi.org/10.1111/j.1745-9133.2008.00528.x

Nedobezhkin, S. V. (2002). The role of the militia of the RSFSR in the fight against crime in the context of the new economic policy (1921-1928) (Abstract of dissertation) (p. 22). Moscow.

Sanukov, K. N. (2003). "Gornomariski question” in the late 1920ths-Early 1930. The Mari archaeological bulletin, 13, 101 .

Sultanbekov, B. F., \& Khakimzhanov, R. (2002). Political repression in Tatarstan (p. 21). Kazan.

The legislation on religious cults: Sat. materials and documents (pp. C. 83-96). (1971). Moscow.

The national regional Congress of the Mari. (2008). The Congress of the Mari people: documents and materials. (1917-2004th, p. 108). Yoshkar-Ola.

The power and soviet society in the $1917^{\text {th }}-1930^{\text {th }}$ (New sources). (2000). Native history, $1,128$.

\section{Copyrights}

Copyright for this article is retained by the author(s), with first publication rights granted to the journal.

This is an open-access article distributed under the terms and conditions of the Creative Commons Attribution license (http://creativecommons.org/licenses/by/3.0/). 